\title{
Metabolism and metastasis: in the bone marrow and beyond
}

\author{
Sérgio Dias \\ From 16th International Charles Heidelberger Symposium on Cancer Research \\ Coimbra, Portugal. 26-28 September 2010
}

Cancer cell metabolism has been in and off the spotlight for the last 80 years or so. Since the milestone studies of Warburg, much has been learned about the molecular basis by which cancer cells utilize resources (metabolic) in a much efficient manner than their normal cell counterparts. Recent advances have clearly shown the metabolic pathways interact with and modulate, signaling pathways that control cell proliferation, senescence, apoptosis, angiogenesis, among others. As a result, cancer is being increasingly recognized as a systemic (and evidently metabolic) group of diseases. Nevertheless, much less is known concerning the eventual role of metabolic pathways in the selection of particular tumor cell traits/phenotypes. The metabolic regulation of the microenvironment, and the ways by which metabolic pathways alter the cross-talk between cancer cells and other elements of the microenvironment, is currently one of our main scientific interests. I will present our latest findings on the role of lipid metabolism in the selection of metastatic behavior by tumor cells. Using models of hematological and solid cancers, I will present data showing the metabolic alterations in microenvironment gives instructive cues that regulate/modulate the metastatic potential of cancer cells.

Submit your next manuscript to BioMed Central and take full advantage of:

- Convenient online submission

- Thorough peer review

- No space constraints or color figure charges

- Immediate publication on acceptance

- Inclusion in PubMed, CAS, Scopus and Google Scholar

- Research which is freely available for redistribution 